\section{Martha's revenge}

David L. Hull

Biophilia: The Human Bond with Other Species.

By Edward O. Wilson.

Harvard University Press: 1984. Pp. 157. $\$ 16.50, £ 13.20$.

IN this, his most recent book, E. O. Wilson presents three interrelated messages - that science provides a sort of knowledge that the humanities cannot produce; that genes are more important in making us what we are than many of us would like to believe; and that buried in our genetic make-up are a variety of propensities including a fascination for other living creatures and an unconscious longing for an environment such as the savannas in which we evolved. Wilson has pursued these themes before in a variety of guises - a general text, a philosophical treatise and, with C. J. Lumsden, dressed up in mathematical garb. In Biophilia he tries his hand at a more literary approach.

From its beginnings, science has found itself in conflict with not only theology but also the humanities, if for no other reason than theologians and humanists controlled the universities. Poets and literary figures complain that scientific knowledge destroys any genuine appreciation of nature; as Tennyson put this conviction, "Science grows and Beauty dwindles". Scientists, it is said, reduce the wonders of nature to a ceaseless war between selfish genes and explain humankind's higher faculties in terms of neurons and the hormone-secreting cells of the limbic system. Although scientists currently dominate the intellectual scene, defenders of the humanities retain some of their old feeling of superiority. Perhaps scientists can lay trans-Atlantic cables and unravel the molecular structure of the genetic material, but they can never hope to provide the higher sorts of understanding afforded by the humanities. Martha might well busy herself serving the guests, but Mary seated at her saviour's knee has the better part.

Wilson has written for his scientific audience several times over. In Biophilia he sets his sights on the great masses on the other side of C. P. Snow's great cultural divide, those readers who are more impressed by striking imagery than by scientific argument and masses of data. If humanists are the "shamans of the intellectual tribe, wise men who interpret knowledge and transmit the folklore, rituals, and sacred texts" (p.58), then Wilson will become a shaman. Here his style is consciously literary, a series of images designed to evoke the appropriate response in his reader. A peccary stolen from its natural habitat and tethered beneath the eaves of a rude hut becomes a "mute speaker trapped inside the unnatural clearing, like a messenger to me from an unexplored world" (p.5). The mythical status of the serpent hints at the hold that our evolutionary past still has on us. The adventures which Wilson had as a young boy with snakes in the woods and pools around his home in the Panhandle of northern Florida illustrate the aversion and fascination which human beings have for snakes. His scientific description of the Bird of Paradise becomes a "metaphor of what humanists dislike most about science"' (p.54).

For me at least, Wilson's attempts at this more literary style are effective. Everyone knows that the Sun is the ultimate source of energy for life on Earth. As Wilson puts it, "After the sun's energy is captured by the green plants, it flows through chains of organisms dendritically, like blood spreading from the arteries into networks of microscopic capillaries"' (p.8). The most distinctive sound in the primary tropical forest, according to Wilson, is a "sharp crack like a rifle shot, followed by whoosh and a solid thump. Somewhere a large tree, weakened by age and rot and top heavy from layers of vines, has chosen that moment to fall and end decades or centuries of life' (p.27). To help his readers visualize the evolutionary process, Wilson contrasts various time frames. Everyone is familiar with organismic time: a leafcutter ant returns to its nest and drops the bit of leaf it has been carrying ( $a$ feat equivalent to a man running a four-minute mile while carrying 750 pounds). In biochemical time, organisms freeze in their tracks as a "nerve cell discharges: along the length of its membrane, the voltage drops as sodium ions flow inward"' (p.42). At a level higher than the single organism, a leafcutter colony resembles a gigantic amoeba, a sort of super-organism. "Its foraging columns snake out like pseudopods to engulf and shred plants, while their stems pull the green pieces down holes into the fungus gardens" (p.36). In evolutionary time, even colonies lose their identity as they merge into an even more inclusive entity enlarging its territory, congealing into local populations, speciating and becoming extinct.

Wilson tries to give the humanities their just due. "The aim of art is not to show how or why an effect is produced (that would be science) but literally to produce it" (p.62). But with this one exception scientists can do everything that artists and writers can do and more. "Scientific innovation sometimes sounds like poetry, and I would claim that it is, at least in the earliest stages. The ideal scientist can be said to think like a poet, work like a clerk, and write like a journalist. The ideal poet thinks, works, and writes like a poet" (p.62). A poet can elicit images in us, but he "refuses to take us any further. If he goes on the precise image will melt into abstract descriptions; light and beauty will congeal into rows of formulas"' (pp. 75-76).

Do I agree with Wilson's main messages?
How good are the arguments he presents? Has he made the right distinctions? To ask these questions is to miss the intent of the book. It is to elicit images and appropriate emotional responses. The clearing of jungles in the Amazon to make room for bony white cattle "can be defended (with difficulty) on economic grounds, but it is like burning a Renaissance painting to cook dinner"' (p.25). This is not an argument, but it does the job as well or, for most people, better. In Biophilia Wilson uses the traditional techniques of the humanities to get his messages across, and one of them is that the humanities are not good enough, that the truths afforded by science transcend those of the humanities. In this book Martha gets her revenge.

David L. Hull is Professor of Philosophy at Northwestern University, Evanston, Illinois.

\section{Ecosystems unlocked}

\section{Mark Williamson}

\section{Key Environments.}

General editor John Treherne.

Sahara Desert. Edited by J.L. CloudsleyThompson. Pp.348. Galapagos. Edited by R. Perry. Pp.321. Madagascar. Edited by A. Jolly, P. Oberlé and E.R.

Albignac. Pp.239.

Pergamon: 1984. Each volume 114.95 , $\$ 23.95$.

WHAT is a "key" environment? For this series it is taken to be one of international ecological importance which is now, or soon will be, under threat of disturbance or destruction. Eight volumes have been advertised so far, and three are to hand; the others promised deal with Amazonia, Antarctica and Malaysia, and there will be two marine ones, on the Red Sea and the Western Mediterranean.

Is it possible to "provide specialists, as well as those who have an interest in the conservation of nature as a whole, with the essential facts [for] practical and effective conservation action" in books of 300 pages written by 20 or so authors? Not really: what in fact has been achieved are reasonably comprehensive and on the whole stimulating accounts of standard natural history, that is, geology and climate, higher plants, vertebrates. The coverage of conservation or management as such is meagre, and there is certainly not enough information to build, say, even a crude model of the effects of different strategies. Rather, Key Environments is "a scientifically accurate, concise and well-illustrated series of accounts" which does indeed "summarise the present knowledge of the flora and fauna".

The format is uniform, $18 \times 24 \mathrm{~cm}$, well set out and structured, and with black-andwhite photographs or line drawings to nearly every page. The reproduction of 